\title{
THE ROLE OF BOSNIAK CLASSIFICATION IN THE ASSESSMENT OF RENAL CYSTIC MASSES AND IN THE THERAPEUTICAL PROTOCOL
}

\author{
Radu ANGHEL ${ }^{1}$, Lucian IORGA ${ }^{1}$, Dragos MARCU ${ }^{1,2 \bowtie}$, Dan SPINU1,2, Ion MOTOFEI ${ }^{3}$, \\ Ana Maria A. STANESCU ${ }^{4}$, Bogdan SOCEA ${ }^{3}$, Andra I. SUCEVEANU ${ }^{5}$, Elvira BRATILA ${ }^{6}$, \\ Dan MISCHIANU1,2,7, Ovidiu BRATU1,2,7
}

${ }^{1}$ Clinic of Urology, University Emergency Central Military Hospital „Dr. Carol Davila“, Bucharest, Romania

${ }^{2}$ University of Medicine and Pharmacy „Carol Davila“, Clinical Departament 3, Bucharest, Romania

3 "Carol Davila" University of Medicine and Pharmacy, Department of Surgery, Emergency Clinical Hospital "St. Pantelimon", Bucharest, Romania

${ }^{4}$ „Carol Davila“ University of Medicine and Pharmacy, Bucharest, Romania

${ }^{5}$ Faculty of Medicine, Ovidius University, Constanta, Romania

${ }^{6}$ „Carol Davila“ University of Medicine and Pharmacy, Clinic of Obstetrics and Gynecology, „Panait Sarbu“ Hospital, Bucharest, Romania

${ }^{7}$ Academy of Romanian Scientists

Received 03 July 2018, Accepted 10 Aug 2018

https://doi.org/10.31688/ABMU.2018.53.3.21

\section{Abstract}

One of the most frequent kidney pathologies encountered in daily practice is represented by the presence of renal cysts. Most of them are asymptomatic and are found accidentally during periodical check-ups because they don't have clinical signs until they grow and compress the surrounding organs. We have reviewed the current data regarding this pathology, in order to underline the risk of malignant transformation and its impact on the patient's life. It is estimated that the prevalence rate of renal cysts in the general population is approximately $10 \%$ and it increases with age. Imaging investigations, such as contrast tomography or magnetic resonance imaging, are essential for establishing the cysts characteristics, especially when

\section{Résumé}

Le role de la classification Bosniak dans l'évaluation des masses kystiques rénales et dans le protocole thérapeutique

Une des pathologies rénales les plus fréquentes dans la pratique quotidienne est la présence de kystes rénaux. La plupart d'entre eux sont asymptomatiques et se retrouvent accidentellement lors des examens périodiques, car ils ne présentent aucun signe clinique tant qu'ils ne se développent pas et ne compriment pas les organes environnants. Nous avons passé en revue les données actuelles concernant cette pathologie, afin de souligner le risque de transformation maligne et son impact sur la vie du patient. On estime que le taux de 
ultrasonography raises the suspicion of a modified renal cyst, as well as in guiding the therapeutical protocol. The Bosniak classification is based on contrast tomography scans and has allowed the standardization of the kidney cysts, considering their characteristics. More attention should be given to Bosniak IIF and III cystic renal masses, which contain thickened walls and more septa, but no enhanced nodules/soft tissue components, because more than half of these cysts can have a malignant component.

Keywords: renal cysts, Bosniak classification, malignant transformation. prévalence des kystes rénaux dans la population générale est d'environ $10 \%$ et qu'il augmente avec l'âge. Les examens d'imagerie, tels que la tomographie de contraste ou l'imagerie par résonance magnétique, sont essentiels pour établir les caractéristiques des kystes, en particulier lorsque l'échographie soulève la suspicion d'une modification du kyste rénal, ainsi que pour guider le protocole thérapeutique. La classification de Bosniak est basée sur la tomographie de contraste et a permis la standardisation des kystes rénaux, compte tenu de leurs caractéristiques. Une plus grande attention devrait être portée aux masses rénales kystiques de Bosniak IIF et III, qui contiennent des parois épaissies et plus de septa, mais pas de composants nodules / tissus mous améliorés, car plus de la moitié de ces kystes peuvent avoir une composante maligne.

Mots-clés: kystes rénaux, classification bosniaque, transformation maligne.

using the PubMed database in order to underline the importance of this pathology.

Cystic kidney lesions are usuallyasymptomatic, being diagnosed accidentally during ultrasonography ${ }^{1,2}$. Renal cysts become symptomatic when they increase in size and compress the surrounding organs. Therefore, these patients can present symptoms such as lumbar or flank pain, especially during physical activity, a palpable lumbar mass that can mimic other renal or retroperitoneal tumors ${ }^{3,4}$. It may also compress the urinary pathway, leading to hydronephrosis and to the atrophy of the renal parenchyma. Quite often, the patients with multiple renal cysts will eventually lose the function of that kidney, due to the compression exerted by the cysts on the renal parenchyma. Before establishing the diagnosis of a destroyed kidney and the indication of nephrectomy it is mandatory to perform renal scintigraphy in order to assess the renal function ${ }^{5,6}$.These patients will unfortunately develop chronic renal failure that may impose dialysis ${ }^{7,8}$. Other important complications that can appear as a result of the urinary stasis are hydroelectrolytic imbalances that may further lead to arrhythmias ${ }^{9,10}$. Like any other renal masses, renal cysts, depending on their size and compressive effect on the surrounding tissues, can also determine persistent high blood pressure ${ }^{11,12}$. Other rare complications are dyspnea, neurological deficits, vena cava syndrome ${ }^{13,14}$. According to literature,renal cysts are one of the most common findings during imaging investigations $s^{15,16}$, their appearance being related to risk factors such as smoking, male sex, nephrolithiasis or aging ${ }^{17}$. We have reviewed the current data about renal cysts and the risk of malignant transformation

\section{THE BOSNIAK CLASSIFICATION}

The Bosniak classification was developed in 1986 and since then it has been used to evaluate renal cystic masses and to guide the therapeutical management ${ }^{18}$. The Bosniak criteria may also be useful for ultrasound and magnetic resonance imaging evaluation. Both imaging techniques have similar results in terms of cystic renal masses assessment.

According to the Bosniak criteria, kidney cysts can be classified as follows:

Type I: implies the presence of a simple kidney cyst,which represents the majority of of kidney cysts, usually detected during imaging investigations for other pathologies. They have homogeneous content with fluid attenuation (0-20 UH), regular contour and a clear interface between the fluid content and the renal parenchyma, without the presence of intracystic septa nor calcifications ${ }^{19,20}$.

Type II: compared to type I kidney cysts, this type of kidney cysts is characterized by the presence of thin septa, usually with a thickness less than $1 \mathrm{~mm}$, as well as linear, parietal or septal calcifications ${ }^{21}$.

Type IIF: this type was included in 1993, because there was a group of lesions that could not be classified as Bosniak III and due to the fact that more complications could appear for this type of cysts compared to the type II Bosniak cyst. These lesions may prove difficult to assess, due to the fact that they present multiple thin or slightly thickened septa, minimally 
thickened walls and regular contour. Kidney hyperdense cysts are included in his category ${ }^{22,23}$.

Type III: presents irregular and thick septa, wall thickening and contrast enhancement, with or without calcifications. They can appear as multilocular, hemorrhagic or infected cyst. These cysts may prove challenging when establishing their benignant or malignant character ${ }^{24}$.

Type IV: this category is characterized by the presence of a malignant cystic mass, which can present imaging characteristics similar to those encountered in a type III kidney cyst. Unlike the type III cyst, the type IV cyst has a solid component, that can be observed near the walls or near the intracystic septa. These renal masses must be considered as being renal carcinoma, with clear surgery indication, because they are malign in $95-100 \%$ of the cases ${ }^{25,26}$.

Even if a simple asymptomatic Bosniak type I cyst is found, a regular follow-up mustbe performed at least every twelve months. In our clinic, we have encountered patients, who have presented themselves seeking medical advice and treatment for a simple renal colic and during ultrasonography we have discovered the presence of a Bosniak type I cyst. We mention the case of a patient who presented for intermittent lumbar pain, that appeared especially during sustained physical activity. During the ultrasound examination we have discovered the presence of a simple renal cyst of $5 / 7 \mathrm{~cm}$. After being informed about his pathology and about the need of periodical evaluation, the patient neglected these recommendations. Several years later, at a routine check-up, it was discovered that the cyst had changed its characteristics: from a simple Bosniak type I renal cyst it had transformed into a cyst with irregular and thick septations and with a solid component, these changes being suggestive for a Bosniak IV renal cyst. Therefore, the surgical indication was certain. We have performed radical nephrectomy and the histopathological examination had confirmed its malignant character. This is why regular follow-ups are necessary after discovering the presence of a renal cyst.

Another study conducted by Bata et al has showed that Bosniak type III cysts are more likely to be malignant than it was initially expected. The study was made on 19 patients with radiological diagnosis of Bosniak type III cysts. Nephron sparing surgery was performed in 13 cases and the remaining six patients have undergone total nephrectomy. The authors have reported that only 3 patients presented hematuria before the diagnosis was established and that the other patients have complained of flank pain or were asymptomatic. Histopathological analysis confirmed that 16 out of 19 lesions were conventional clear cell renal cell carcinomas $(84 \%)^{27}$.
The Bosniak classification was created in 1986 in order to ensure a more accurate diagnosis, as well as to ease up the therapeutical protocol. The magnetic resonance imaging technique has an excellent soft-tissue resolution, that can bring a more sensitive information about the solid component renal cyst compared to CT examination ${ }^{28}$. Older studies have shown a surprising variability in the percentage of malignant Bosniak III cysts (31\%-100\%), these numbers being based on small series studies that used older CT technology $y^{29}$. Other six studies (each one included more than 30 renal cystic masses) have found that approximately $65 \%$ of the Bosniak III lesions were malignant ${ }^{30}$. Over all, all recent studies show that more than $50 \%$ of the Bosniak III cysts have a malignant component. However, these previous studies have serious limitations because of the older type of CT used.

Pathological studies have revealed that the most frequent type of malignant renal tumors is usually conventional clear cell renal carcinoma. It is estimated that only $4-15 \%$ of all renal cell carcinomas is represented by cystic growth pattern ${ }^{31}$. Several studies have shown that there is a higher rate of renal carcinoma in the presence of a precursor cystic lesion ${ }^{32}$.

Recent studies revealed that the use of intravenous sonographic contrast agent may allow for a better detection of a complex cystic lesions, even in cases of very thin septa (hair-like), with an accuracysuperior to $\mathrm{CT}^{33}$. The disadvantage of this procedure is the cost of the contrast agent, that is higher than the iodinated contrast agent, and low reproducibility of the method.

\section{Conclusions}

The Bosniak classification of renal cystic masses has allowed the standardization and the management of renal cystic lesions. This classification can also be used for the magnetic resonance imaging technique and not only for the CT examination. Ultrasonography remains an excellent method used for the screening of renal cystic lesions. More attention should be paid to Bosniak IIF or III lesions based on magnetic resonance imaging, which contains thickened walls and more septa, but no enhanced nodules/soft tissue components, because more than half of them can have a malignant component.

\section{Compliance with Ethics Requirements:}

„The authors declare no conflict of interest regarding this article"

"No funding for this study" 


\section{References}

1. Tada S, Yamagishi J, Kobayashi H, Hata Y, Kobari T. The incidence of simple renal cyst by computed tomography. Clin Radiol 1983;34:437-9.

2. Ravine D, Gibson RN, Donlan J, Sheffield LJ. An ultrasound renal cyst prevalence survey: specificity data for inherited renal cystic diseases. Am J Kidney Dis 1993;22:803-7.

3. Constantinoiu S, Birla R, Iosif C, et al.Difficulties in diagnosis and surgical treatment of a giant retroperitoneal lipoma.Chirurgia 2009;104(3):363-367.

4. Marcu RD, Spinu AD, Socea B, et al. Castleman's disease clinical, histological and therapeutic features. Rev Chim 2018, 69(4): 823-830.

5. Peride I, Rădulescu D, Niculae A, Ene V, Bratu OG, Checheriță IA.Value of ultrasound elastography in the diagnosis of native kidney fibrosis. Med Ultrason 2016;18(3):362-9.

6. Raluca Mititelu, Ovidiu Bratu. Radionuclide imaging. An update on the use of dynamic renal scintigraphy. Modern Medicine2017;24(4):199-203.

7. Checheriță IA, Smarandache D, Rădulescu D, et al.Calcific uremic arteriolopathy in hemodialyzed patients.Chirurgia 2013; 108(5):736-40.

8. Rădulescu D, Balcangiu Stroescu A, Pricop C, et al. Vitamin $\mathrm{K}$ influence on cardiovascular mortality in chronic hemodialysed patients.Rev Chim2017;68(1):52-54.

9. Diaconu CC, Manea M, Iancu MA, et al. Hyponatremia in patients with heart failure: a prognostic Marker. Rev Chim 2018; 69(5):1071-1074.

10. Diaconu CC, Stanescu AMA, Pantea Stoian A, et al. Hyperkalemia and cardiovascular diseases: new molecules for the treatment. Rev Chim 2018;69(6):1367-1370.

11. Diaconu CC, Drăgoi CM, Bratu OG, et al. New approaches and perspectives for the pharmacological treatment of arterial hypertension. Farmacia 2018;66(3):408-415.

12. Niculae A, Peride I, Marinescu-Paninopol A, et al. Renal artery bilateral arteriosclerosis, cause of resistant hypertension in hemodialysed patients.Rom J Morphol Embryol 2016;57(2):591-4.

13. Paraschiv B, Dediu G, Iancu A, Bratu O, Diaconu C. Superior vena cava syndrome. Arch Balk Med Union2017; 52(1): 39-43

14. Belciu D, Horodinschi RN, Ionescu C, et al. Right hemiplegia and dyspnea: what is the link between? Arch Balk Med Union2017;52(3):353-358.

15. Israel GM, Bosniak MA. How I do it: evaluating renal masses. Radiology 2005;236:441-50.

16. Lee J, Darcy M. Renal cysts and urinomas. Semin Intervent Radiol2011;28:380-91.

17. Chang CC, Kuo JY, Chan WL, et al. Prevalence and clinical characteristics of simple renal cyst. J Chin Med Assoc 2007;70:486-91.
18. Lévy P, Hélénon O, Merran S, et al. Cystic tumors of the kidney in adults: radio-histopathologic correlations. J Radiol 1999;80:121-33.

19. Bosniak MA. Diagnosis and management of patients with complicated cystic lesions of the kidney.Am J Roentgenol 1997;169:819-21.

20. Brătilă E, Ionescu OM, Berceanu C, Coroleucă CA, Ardeleanu CM, Mehedințu C. Vaginal epithelioid angiosarcoma: a rare case. Rom J Morphol Embryol 2016; 57(3):11311135

21. Silverman SG, Israel GM, Herts BR, et al. Management of the incidental renal mass. Radiology 2008;249:16-31.

22. Bertolotto M, Zappetti R, Cavallaro $M$, et al. Characterization of atypical cystic renal masses with MDCT: comparison of 5-mm axia images and thin multiplanar reconstructed images. Am J Roentgenol 2010;195:693-700.

23. Israel GM, Hindman N, Bosniak MA. Evaluation of cystic renal masses: comparison of CT and MR imaging by using the Bosniak classification system. Radiology 2004;231:36571.

24. Israel GM, Bosniak MA. An update of the Bosniak renal cyst classification system. Urology 2005;66:484-8.

25. Rocha de Miranda CMN, Maranhão CPM, dos Santos CJJ. Bosniak classification of renal cystic lesions according to multidetector computed tomography findings. Radiol Bras $2014 ; 47(2): 115-121$

26. Diaconescu D, Pantea Stoian A, Socea LI, et al. Hepatorenal syndrome: a review. Arch Balk Med Union 2018;53(2):239-245.

27. Bata P, Tarnoki AD, Tarnoki DL, et al. Bosniak category III cysts are more likely to be malignant than we expected in the era of multidetector computed tomography technology. J Res Med Sci 2014;19(7):634-8.

28. Bosniak MA. The current radiological approach to renal cysts. Radiology 1986;158(1):1-10.

29. Graumann O, Osther SS, Osther PJ. Characterization of complex renal cysts: a critical evaluation of the Bosniak classification. Scand J Urol Nephrol 2011;45(2):84 - 90 .

30. Hartman DS, Davis CJ Jr, Johns T, Goldman SM. Cystic renal cell carcinoma. Urology 1986;28:145-53.

31. Charboneau JW, Hattery RR, Ernst EC 3rd, James EM, Williamson B Jr, Hartman GW. Spectrum of sonographic findings in 125 renal masses other than benign simple cyst. Am J Roentgenol 1983;140:87-94.

32. Quaia E, Bertolotto M, Cioffi V, et al. Comparison of contrastenhanced sonography with unenhanced sonography and contrast enhanced CT in the diagnosis of malignancy in complex cystic renal masses. Am J Roentgenol 2008;191:123949.

33. Inci E, Hocaoglu E, Aydin S, et al. Diffusion-weighted magnetic resonance imaging in evaluation of primary solid and cystic renal masses using the Bosniak classification. Eur J Radiol 2012;81:815-20. 